\title{
Serological investigation and PCR in detection of pathogenic leptospires in snakes ${ }^{1}$
}

\author{
Natália P. Biscola ${ }^{2,3}$, Felipe Fornazari ${ }^{4}$, Eduardo Saad ${ }^{2,3}$,Virginia B. Richini-Pereira ${ }^{4}$, \\ Michelle V. Campagner ${ }^{2,3}$, Helio Langoni ${ }^{4}$, Benedito Barraviera ${ }^{2,3}$ \\ and Rui S. Ferreira Junior ${ }^{2,3^{*}}$
}

\begin{abstract}
Biscola N.P., Fornazari F., Saad E., Richini-Pereira V.B., Campagner M.V., Langoni H., Barraviera B. \& Ferreira Junior R.S. 2011. Serological investigation and PCR in detection of pathogenic leptospires in snakes. Pesquisa Veterinária Brasileira 31(9):806-811. Centro de Estudos de Venenos e Animais Peçonhentos, Universidade Estadual Paulista, Fazenda Experimental Lageado, Rua José Barbosa de Barros 1780, Botucatu, SP 18610-307, Brazil. Email: rseabra@cevap.org.br

Detection of Leptospira by PCR had not yet been described in snakes. This study investigated, by microscopic agglutination test (MAT) and PCR, the presence of antibodies to Leptospira spp. and Leptospira spp., respectively, in venomous and non-venomous wildlife and captivity snakes. All snakes were divided into three groups to be compared: Group 1 (wildlife snakes - WS); Group 2 (snakes in intensive captivity - IC), and Group 3 (collective semiextensive captivity-CC). Of the 147 snakes studied, 52 (35.4\%) were positive for leptospirosis by MAT, 8 (15.4\%) belonging to Group 1 (WS), 34 (65.4\%) to Group 2 (IC) and $10(19.2 \%)$ to Group 3 (CC). Jararaca (Bothrops jararaca) presented the highest average titer $(66.7 \%, \mathrm{~N}=22$ / 33) among the three group studied, and Hardjo prajtino was the most prevalent serovar (88.5\%, N=46/52), with titers varying from 100 to 3200. Leptospira interrogans was revealed by PCR in kidney and liver of caiçaca (Bothrops moojeni) and jararaca-pintada (Bothrops pauloensis), showing $100 \%$ and $93 \%$ identity respectively. Future studies should be carried out for better understanding of the role of snakes as a reservoir of Leptospira in nature.
\end{abstract}

INDEX TERMS: PCR, MAT, Leptospira spp., snakes, Bothrops jararaca, Bothrops moojeni, Hardjo prajtino.

RESUMO.- [Investigação sorológica e PCR na detecção de leptospiras patogênicas em serpentes.] A detecção de Leptospira pela técnica de PCR não havia sido descrita em serpentes. Este estudo investigou pelo teste de aglutinação microscópica (MAT) e PCR, a presença de anticorpos anti-Leptospira spp. e Leptospira spp., respectivamente, em serpentes peçonhentas e não peçonhentas de vida livre e de cativeiro. As serpentes foram divididas em três grupos para comparação: Grupo 1 (serpentes recém-chegadas da natureza WS); Grupo 2 (serpentes em regime de cativeiro intensivo IC) e Grupo 3 (serpentes em regime de cativeiro coletivo semi-

\footnotetext{
${ }^{1}$ Received on October 28, 2010.

Accepted for publication on June 21, 2011.

${ }^{2}$ Centro de Estudos de Venenos e Animais Peçonhentos (CEVAP), Universidade Estadual Paulista (Unesp), Fazenda Experimental Lageado, Rua José Barbosa de Barros 1780, Botucatu, SP 18610-307, Brazil. *Corresponding author: rseabra@cevap.org.br

${ }^{3}$ Escola de Medicina, Universidade Estadual Paulista (Unesp), Campus de Botucatu, Distrito de Rubião Júnior s/n, Botucatu, SP 18618-970.

${ }^{4}$ Núcleo de Pesquisa em Zoonoses (Nupezo), Escola de Medicina Veterinária e Zootecnia, Unesp, Distrito de Rubião Júnior s/n, Botucatu, SP 18.618-000.
}

extensivo - CC). Do total de 147 serpentes estudadas, 52 $(35,4 \%)$ foram positivas para leptospirose pelo MAT, as quais $8(15,4 \%)$ pertenciam ao Grupo 1 (WS), $34(65,4 \%)$ ao Grupo 2 (IC) e 10 (19,2\%) ao Grupo 3 (CC). Das espécies estudadas, a jararaca (Bothrops jararaca) apresentou maior soropositividade $(66,7 \%, \mathrm{~N}=22 / 33)$. 0 sorovar mais prevalente foi o Hardjo prajtino $(88,5 \%, \mathrm{~N}=46 / 52)$ e os títulos variaram de 100 a 3200. Leptospira interrogans foi revelada por PCR nos rins e no fígado de caiçaca (Bothrops moojeni) e de jararaca-pintada (Bothrops pauloensis), mostrando 100\% e 93\% de identidade, respectivamente. Futuros estudos devem ser realizados para melhor compreensão do papel das serpentes como reservatório de leptospiras na natureza.

TERMOS DE INDEXAÇÃO: PCR, MAT, Leptospira spp., serpentes, Bothrops jararaca, Bothrops moojeni, Hardjo prajtino.

\section{INTRODUCTION}

Leptospirosis is a worldwide zoonotic disease with high occurrence in tropical countries. Rats are considered the most significant reservoirs. In tropical countries other animals may 
also be important sources of infection, such as cattle, horses, swine, dogs and wildlife (Weekes et al. 1997, Blancou 2005, Aguiar et al. 2006, Ghneim et al. 2007, Hashimoto et al. 2007). Among wildlife animals, venomous and non-venomous snakes may be considered natural reservoirs, mainly due to their diet, which is based on rodents (Hyakutake at al. 1980).

In Brazil, Leptospira in snakes were first investigated in 1976 by Hyakutake et al. that verified remarkable predominance of serovar Andamana (80.6\%). Abdulla \& Karstad (1962) showed that captive snakes may acquire leptospirosis due to their food and water intake and also by direct contact with each other.

Leptospira is detectable through urine or tissues by culture, dark field microscopy, immuno-staining or polymerase chain reaction (PCR) (Adler and Moctezuma 2010). The most widely used microscopic agglutination test (MAT) has the advantage of being specific for serovars and serogroups. Several PCR protocols for detection of Leptospira DNA in clinical material have been developed since the 1990s and most of them reported a high sensitivity. Compared with dark field microscopy and immuno-staining, polymerase chain reaction (PCR) has several advantages as rapidity, simplicity and low-cost (Romero \& Yasuda 2006, Adler \& Moctezuma 2010). However, no protocol for Leptospira detection in snakes by PCR has been described up to this moment.

The aim of this study was to investigate the presence of Leptospira spp. and Leptospira spp. antibodies in venomous and non-venomous snakes using MAT and PCR methods to understand the role of wildlife and captive snakes as reservoirs in nature.

\section{MATERIALS AND METHODS}

Blood samples ( $\mathrm{n}=147$ ) were collected from the caudal vein of 127 venomous and 20 non-venomous snakes distributed into three groups: Group 1 (G1): 35 wildlife snakes (WS) including six jararacas (Bothrops jararaca), three jararacas-pintada (Bothrops pauloensis), 20 cascavéis (Crotalus durissus terrificus), four jibóias (Boa constrictor amarali), one jararaca-da-seca (Bothrops leucurus), and one caiçaca (Bothrops moojeni). Group 2 (G2): 64 snakes in intensive captivity (IC) kept in individual plastic boxes adapted to their size under controlled temperature and humidity. The boxes were cleaned daily, water was given "ad libitum" and the snakes were fed with one mouse every 30 days. This group comprised 15 caiçacas (Bothrops moojeni), 15 jararacas (Bothrops jararaca), 14 jararacas-pintada (Bothrops pauloensis) and 20 cascavéis (Crotalus durissus terrificus). Group 3 (G3): 48 snakes kept in semi-extensive collective captivity (CC) in heated stalls with running water and solarium. This group comprised 12 jibóias (Boa constrictor amarali), 12 jararacas (Bothrops jararaca), 20 cascavéis (Crotalus durissus terrificus) and four caninanas (Spilotes pullatus). The G2 and G3 snakes were maintained in captivity for more than one year until tests were carried out.

Blood samples were collected and centrifuged at $1000 \mathrm{G}$ for 10 min. Serum was stored in $1.5 \mathrm{~mL}$ microtubes at $-20^{\circ} \mathrm{C}$ for batch testing. This study was developed after receiving authorization from the Instituto Chico Mendes de Conservação da Biodiversidade (ICMBio) and Animal Research Ethics Committee (CEEA) number $778 / 2010$.

Samples were analyzed using MAT as recommended by the World Organization for Animal Health Animal (OIE) (Faine 1982; Office World Organization for Animal Health Animal 2009). Samples
Table 1. Species, serogroups and respective serological variants for Leptospira diagnosis using MAT

\begin{tabular}{|c|c|c|c|}
\hline Species & Serogroup & Serovar & Strain \\
\hline $\begin{array}{l}\text { Leptospira } \\
\text { interrogans }\end{array}$ & Australis & $\begin{array}{l}\text { Australis } \\
\text { Bratislava }\end{array}$ & $\begin{array}{c}\text { Ballico } \\
\text { Jez-bratislava }\end{array}$ \\
\hline $\begin{array}{l}\text { Leptospira } \\
\text { interrogans }\end{array}$ & Autumnalis & $\begin{array}{l}\text { Autumnalis } \\
\text { Butembo }\end{array}$ & $\begin{array}{c}\text { Akiyami A } \\
\text { Butembo }\end{array}$ \\
\hline $\begin{array}{l}\text { Leptospira } \\
\text { kirshneri }\end{array}$ & Ballum & Castellonis & Castellón \\
\hline $\begin{array}{l}\text { Leptospira } \\
\text { interrogans }\end{array}$ & Bataviae & $\begin{array}{l}\text { Bataviae } \\
\text { Brasiliensis }\end{array}$ & Van Tienen \\
\hline $\begin{array}{l}\text { Leptospira } \\
\text { santarosai }\end{array}$ & & & An 776 \\
\hline $\begin{array}{l}\text { Leptospira } \\
\text { interrogans }\end{array}$ & Canicola & Canicola & $\begin{array}{l}\text { Hond Utrecht } \\
\text { IV }\end{array}$ \\
\hline $\begin{array}{l}\text { Leptospira } \\
\text { weilli }\end{array}$ & Celledoni & Whitcombi & Whitcombi \\
\hline $\begin{array}{l}\text { Leptospira } \\
\text { kirshneri }\end{array}$ & Cynopteri & Cynopteri & $3552 \mathrm{C}$ \\
\hline $\begin{array}{l}\text { Leptospira } \\
\text { interrogans }\end{array}$ & Djasiman & $\begin{array}{l}\text { Djasiman } \\
\text { Sentot }\end{array}$ & $\begin{array}{l}\text { Djasiman } \\
\text { Sentot }\end{array}$ \\
\hline $\begin{array}{l}\text { Leptospira } \\
\text { kirshneri }\end{array}$ & Grippotyphosa & Grippotyphosa & Moska V \\
\hline $\begin{array}{l}\text { Leptospira } \\
\text { interrogans }\end{array}$ & Hebdomadis & Hebdomadis & Hebdomadis \\
\hline $\begin{array}{l}\text { Leptospira } \\
\text { interrogans }\end{array}$ & $\begin{array}{l}\text { Icterohaemor- } \\
\text { raghiae }\end{array}$ & $\begin{array}{c}\text { Copenhageni Itero- } \\
\text { haemorraghiae }\end{array}$ & M 20 RGA \\
\hline $\begin{array}{l}\text { Leptospira } \\
\text { borgpetersenii }\end{array}$ & Javanica & Javanica & $\begin{array}{c}\text { Veldrat Batavia } \\
\text { 46/RA } 94\end{array}$ \\
\hline $\begin{array}{l}\text { Leptospira } \\
\text { nogochii }\end{array}$ & Panama & Panama & CZ $214 \mathrm{~K}$ \\
\hline $\begin{array}{l}\text { Leptospira } \\
\text { interrogans }\end{array}$ & Pomona & Pomona & Pomona \\
\hline $\begin{array}{l}\text { Leptospira } \\
\text { interrogans }\end{array}$ & Pyrogenes & Pyrogenes & Salinem \\
\hline $\begin{array}{l}\text { Leptospira } \\
\text { interrogans }\end{array}$ & Sejroe & $\begin{array}{c}\text { Hardjo } \\
\text { Hardjo prajtino } \\
\text { Hardjo mini } \\
\text { Hardjo ctg } \\
\text { Wolfii }\end{array}$ & \\
\hline $\begin{array}{l}\text { Leptospira } \\
\text { santarosai }\end{array}$ & Shermani & Shermani & LT 821 \\
\hline $\begin{array}{l}\text { Leptospira } \\
\text { borgpetersenii }\end{array}$ & & Tarassovi & $\begin{array}{l}\text { Perepelicin ou } \\
\text { Mitis Johnson }\end{array}$ \\
\hline $\begin{array}{l}\text { Leptospira } \\
\text { biflexa }\end{array}$ & Andamana & Andamana & CH 11 \\
\hline $\begin{array}{l}\text { Leptospira } \\
\text { biflexa }\end{array}$ & Semarangan & Patoc & Patoc I \\
\hline
\end{tabular}

were screened at 1:100 dilution using a battery of 29 live antigen serovar strains (Table 1).

Three animals died of natural causes during the study. Fragments of the heart, spleen, pancreas, intestine, liver and kidney were collected and processed for DNA extraction from these snakes by PCR: one jararaca-pintada (Bothrops pauloensis) from G1 and two caiçacas (Bothrops moojeni) from G2.

Genomic DNA was extracted from tissue samples using a commercially available DNA extraction (llustra Tissue \& Cells genomic Prep Mini Spin ${ }^{\circledR}$ kit, GE Healthcare) and evaluated in spectrophotometer (NanoVue ${ }^{\circledR}$, GE Healthcare).

The amplification of Leptospira spp. DNA was performed utilizing primers LEP-1 (5'-GGCGGCGCGTCTTAAACATG-3') and LEP-2 (5'-TTCCCCCCATTGAGCAAGATT-3') resulting in $330 \mathrm{pb}$ (Mérein 1992). The process carried out in a $25 \mu \mathrm{L}$ solution containing 1 -Taq polymerase buffer $(10 \mathrm{mM}$ Tris $\mathrm{HCl} \mathrm{pH} 8.0,50 \mathrm{mM}$ $\mathrm{KCl}$ ), $1.5 \mathrm{mM} \mathrm{MgCl}, 200 \mu \mathrm{M}$ dNTP, 10 pmol of each primer (LEP-1 and LEP-2), $10 \mathrm{ng}$ of purified DNA and $0.2 \mathrm{U} / \mu \mathrm{l}$ of Taq Platinum DNA polimerase system (Invitrogen). A MasterCycler gradient (Eppendorf) with initial denaturation at $94^{\circ} \mathrm{C}$ for $3 \mathrm{~min}$, followed 
by 30 cycles at $94^{\circ} \mathrm{C}$ for $1 \mathrm{~min}$, then at $63^{\circ} \mathrm{C}$ for $1 \mathrm{~min}$ and $30 \mathrm{sec}$ and a final extension at $72^{\circ} \mathrm{C}$ for 2 min was used.

Aliquots of the PCR products, along with a $100 \mathrm{bp}$ DNA ladder (Invitrogen), were loaded into $2 \%$ agarose gel (Invitrogen) stained with SYBR ${ }^{\circledR}$ safe (Invitrogen) and submitted to electrophoresis in TBE buffer (0.09 M Tris-HCl, $0.09 \mathrm{M}$ boric acid, 2mM EDTA, pH 8.3) for $60 \mathrm{~min}$ at 80V (Electrophoresis Power Supply Model EPS 301; GE Healthcare). The amplified DNA fragments were observed through GelDoc-IT ${ }^{\mathrm{TM}}$ Imaging System, using Vision Works ${ }^{\circledR}$ LS Software.

The amplicons were purified by using ExoSap (USB) and the sequencing reactions were carried out on both strands in a MegaBace $^{\mathrm{TM}} 1000$ (GE-Healthcare). Sequences were analyzed using Chromas 2.3 and Mega 4 software and compared with NCBI database by using BLAST search in GenBank (National Center for Biotechnology Information, Washington, D.C., http://www.ncbi. nlm.nih.gov/BLAST).

Tukey test was employed to compare proportions with $\mathrm{a}=0.05$ (Zar 1999) and to study epidemiological variables and serological test for leptospirosis.

\section{RESULTS}

Of the 147 snakes studied, 52 (35.4\%) were seropositive for leptospirosis by MAT, with eight (15.4\%) in G1 (WS), 34 $(65.4 \%)$ in G2 (IC) and ten (19.2\%) in G3 (CC), according Table 2. Table 3 shows the number of snakes positive for Leptospira using MAT according to group, specie, serovar and titers. Titers varied from 100 to 3200 and Hardjo prajtino was the most prevalent serovar (88.5\%, N=46/52), as shown in Table 3. Jararaca (Bothrops jararaca) $(66.7 \%, \mathrm{~N}=22 / 33)$ showed the highest average titer among the three groups.

Positive amplifications of predictive amplicons of Leptospira spp. were detected in the kidney of one jararaca-pintada (B. pauloensis) (G1) with titer of 200 Hardjo prajtino and two caiçacas (B. moojeni) (G2) with titers of 200 and 1600 Hardjo prajtino, as shown in Fig. 1. When submitted to BLASTn analysis, all the purified and sequenced amplicons revealed $100 \%$ identity with Leptospira interrogans sequences deposited in the GenBank, producing unambiguous fragments

Table 2. Comparison of antibodies to Leptospira seropositivity in the three groups and in the different species studied

\begin{tabular}{|c|c|c|c|c|c|}
\hline Group & $\mathrm{N}$ & Species & $\begin{array}{c}\text { Non } \\
\text { reactive }\end{array}$ & Reactive & Total \\
\hline \multirow[t]{6}{*}{1 (WS) } & $35 \mathrm{~b}$ & Bothrops jararaca & 4 & $2 \mathrm{~A}$ & 6 \\
\hline & & Bothrops pauloensis & 1 & $2 \mathrm{~A}$ & 3 \\
\hline & & Crotalus durissus terrificus & 17 & $3 \mathrm{~B}$ & 20 \\
\hline & & Bothrops moojeni & 1 & $0 \mathrm{~B}$ & 1 \\
\hline & & Bothrops leucurus & 0 & $1 \mathrm{~B}$ & 1 \\
\hline & & Boa constrictor amarali & 4 & $0 \mathrm{~B}$ & 4 \\
\hline \multirow[t]{4}{*}{$2(\mathrm{IC})$} & $64 \mathrm{a}$ & Bothrops jararaca & 4 & $11 \mathrm{~A}$ & 15 \\
\hline & & Bothrops moojeni & 2 & $13 \mathrm{~A}$ & 15 \\
\hline & & Bothrops pauloensis & 5 & $9 \mathrm{~A}$ & 14 \\
\hline & & Crotalus durissus terrificus & 19 & $1 \mathrm{~B}$ & 20 \\
\hline \multirow[t]{4}{*}{$3(\mathrm{CC})$} & $48 \mathrm{~b}$ & Boa constrictor amarali & 11 & $1 \mathrm{~B}$ & 12 \\
\hline & & Bothrops jararaca & 3 & $9 \mathrm{~A}$ & 12 \\
\hline & & Crotalus durissus terrificus & 20 & $0 \mathrm{~B}$ & 20 \\
\hline & & Spilotes pullatus & 4 & $0 \mathrm{~B}$ & 4 \\
\hline Total & & & 86 & 52 & 147 \\
\hline
\end{tabular}

$\chi 2=0.10 . P \leq 0.05$, lowercase letters indicate a statistical analysis among the 3 groups, while capital letters indicate a statistical analysis within each group. Same letters do not differ statistically. WS: wild snakes; IC = intensive captivity; $\mathrm{CC}=$ collective captivity; $\mathrm{N}=$ number of snakes by group.
Table 3. Number of snakes positive for Leptospira using MAT according to group, species, serovar and titers

\begin{tabular}{|c|c|c|c|c|c|c|c|c|}
\hline \multirow[t]{2}{*}{ Group } & \multirow[t]{2}{*}{$\mathrm{N}$} & \multirow[t]{2}{*}{ Serovar } & \multicolumn{6}{|c|}{ Titer $(1 /)$} \\
\hline & & & 100 & 200 & 400 & 800 & 1600 & 3200 \\
\hline \multirow[t]{3}{*}{1 (WS) } & 34 & $\begin{array}{c}\text { Hardjo } \\
\text { prajtino }\end{array}$ & & $2 \mathrm{Bp}$ & $1 \mathrm{Bl}$ & & $2 \mathrm{Bj}$ & \\
\hline & & Sentot & $2 \mathrm{Cdt}$ & & & & & \\
\hline & & Andamana & $1 \mathrm{Cdt}$ & & & & & \\
\hline \multirow[t]{7}{*}{2 (IC) } & 64 & $\begin{array}{c}\text { Hardjo } \\
\text { prajtino }\end{array}$ & $4 \mathrm{Bj}$ & $5 \mathrm{Bj}$ & $3 \mathrm{Bm}$ & $1 \mathrm{Bj}$ & $3 \mathrm{Bm}$ & \\
\hline & & & $1 \mathrm{Bm}$ & $3 B m$ & & $3 \mathrm{Bm}$ & & \\
\hline & & & $4 \mathrm{Bp}$ & $\begin{array}{l}4 \mathrm{Bp} \\
1 \mathrm{Cdt}\end{array}$ & & $1 B p$ & & \\
\hline & & Hardjo mini & $2 \mathrm{Bj}$ & $3 \mathrm{Bj}$ & $1 \mathrm{Bj}$ & & & \\
\hline & & Patoc & & $1 \mathrm{Bj}$ & & & & \\
\hline & & $\begin{array}{l}\text { Gryppo- } \\
\text { thyphosa }\end{array}$ & & & & $1 \mathrm{Bm}$ & & \\
\hline & & Pyrogenes & $1 \mathrm{Bp}$ & & & & & \\
\hline \multirow[t]{2}{*}{$3(\mathrm{CC})$} & 48 & $\begin{array}{c}\text { Hardjo } \\
\text { prajtino }\end{array}$ & $1 \mathrm{Bj}$ & $1 \mathrm{Bj}$ & $3 \mathrm{Bj}$ & & $1 \mathrm{Bj}$ & $2 \mathrm{Bj}$ \\
\hline & & Panama & & $1 \mathrm{Bca}$ & & & & \\
\hline
\end{tabular}

$\overline{\mathrm{WS}}=$ wild snakes; IC = intensive captivity; $\mathrm{CC}$ = collective captivity; $\mathrm{N}=$ number of snakes per group. $\mathrm{Cdt}=$ Crotalus durissus terrificus; $\mathrm{Bm}=\mathrm{Bo}$ throps moojeni $; \mathrm{Bj}=$ Bothrops jararaca $; \mathrm{Bp}=$ Bothrops pauloensis $; \mathrm{Bl}=$ Bothrops leucurus; $\mathrm{Bca}=$ Boa constrictor amarali.

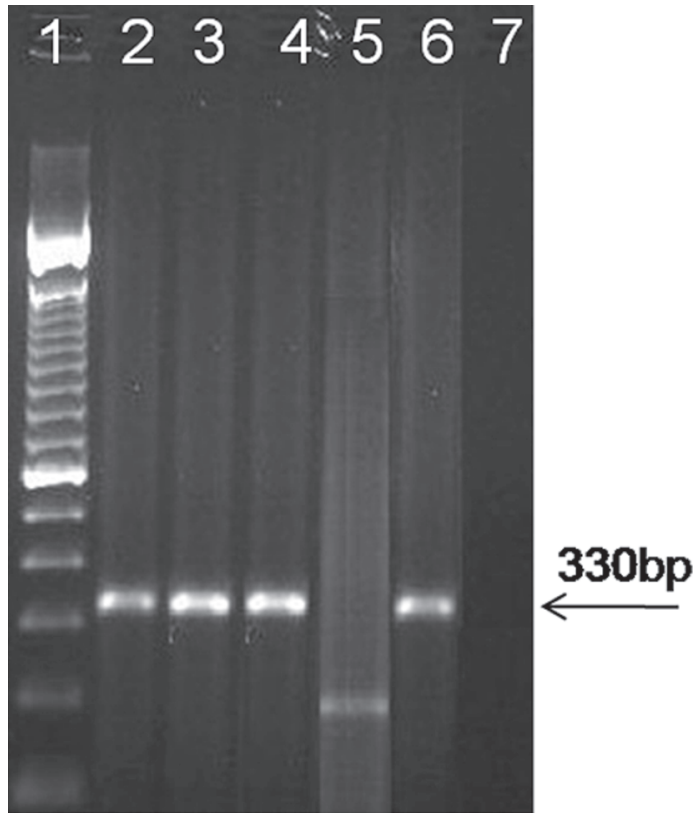

Fig.1. Electrophoresis of the PCR products using primers Lep1 and Lep2 with products of $331 \mathrm{pb}$ in samples of kidney and liver of Bothrops pauloensis and Bothrops moojeni. Lane 1-7. 1) 100bp DNA ladder (Invitrogen), 2) kidney Bothrops moojeni (Group 2), 3) kidney Bothrops moojeni (Group 2), 4) kidney Bothrops pauloensis (Group 1), 5) liver Bothrops pauloensis (Group 1), 6) positive control; 7) negative control.

from 364 bases (Table 4). Liver samples from jararaca-pintada (B. pauloensis- G1) showed one lower band than expected and 93\% sequence identity with Leptospira spp. (Table 4).

\section{DISCUSSION}

Many animals are Leptospira spp. hosts, and each serotype has one or more hosts with different adaptation degrees. The 
Table 4. Nucleotide sequence alignment and percentage of identity on liver and kidney samples of Bothrops pauloensis and Bothrops moojeni

\begin{tabular}{|c|c|c|c|}
\hline Sample & $\begin{array}{l}\text { Species/ } \\
\text { Group }\end{array}$ & Nucleotide sequence alignment & $\begin{array}{c}\% \text { identity/ } \\
\text { GenBank access }\end{array}$ \\
\hline Liver & $\begin{array}{c}\text { Bothrops } \\
\text { pauloensis } \\
\text { G1 }\end{array}$ & $\begin{array}{l}\text { CGGAAAGGCTCAGACAGCGACTACTGTCCAG } \\
\text { GCGTGCGACACTGCGCGGTCGATGTAACATCT } \\
\text { GTGGCGGATAAAGCAATGGCCGACATGAGTC } \\
\text { TCTGGGACTAACTTTCCAGTAACGGTGAAGCG } \\
\text { TAACTACATGGATTGGTCCCGTAGGAGAGTCA } \\
\text { ATAAGGATTTTTCGGGTAAAGATTTATTGCTC } \\
\text { GGAGATGAGCCCGCGTCCGATTAGCTAGCTTG } \\
\text { GTGATGTGTAACAGGCTCACCAAGGCGACGA } \\
\text { TCGGTAGCCTGTGCCTGAGAGTGGTGTTCGGC } \\
\text { CACAATGGAACTGAGACACGGTCCATACTCCT } \\
\text { ACGGCGAGGCATGCAGTTAAGAATCTTGCTCA } \\
\text { ATGGGGGGAAACATGG }\end{array}$ & $\begin{array}{c}93 \%(237 / 265) \\
\text { AY461867.1 }\end{array}$ \\
\hline Kidney & $\begin{array}{c}\text { Bothrops } \\
\text { pauloensis } \\
\text { G1 }\end{array}$ & $\begin{array}{l}\text { CCCTTCTTGGCGGCGCGTCTTAAACATGCAA } \\
\text { GTCAAGCGGAGTAGCAATACTCAGCGGCGA } \\
\text { ACGGGTGAGTAACACGTGGGTAATCTTCCTC } \\
\text { TGAGTCTGGGATAACTTTCCGAAAGGGAAGC } \\
\text { TAATACTGGATGGTCCCGAGAGATCATAAGA } \\
\text { TTTTTCGGGTAAAGATTTATTGCTCGGAGAT } \\
\text { GAGCCCGCGTCCGATTAGCTAGTTGGTGAGG } \\
\text { TAAAGGCTCACCAAGGCGACGATCGGTAGC } \\
\text { CGGCCTGAGAGGGTGTTCGGCCACAATGGA } \\
\text { ACTGAGACACGGTCCATACTCCTACGGGAGG } \\
\text { CAGCAGTTAAGAATCTTGCTCAATGGGGGGA } \\
\text { ACCCTGAAGCAGCGACGCCGCGTGAACGAT } \\
\text { GAA }\end{array}$ & $\begin{array}{c}100 \%(364 / 364) \\
\text { AE010300.2 }\end{array}$ \\
\hline Kidney & $\begin{array}{c}\text { Bothrops } \\
\text { moojeni } \\
\text { G2 }\end{array}$ & $\begin{array}{l}\text { CTTCTTGGCGGCGCGTCTTAAACATGCAAGT } \\
\text { CAAGCGGAGTAGCAATACTCAGCGGCGAAC } \\
\text { GGGTGAGTAACACGTGGGTAATCTTCCTCTG } \\
\text { AGTCTGGGATAACTTTCCGAAAGGGAAGCTA } \\
\text { ATACTGGATGGTCCCGAGAGATCATAAGATT } \\
\text { TTTCGGGTAAAGATTTATTGCTCGGAGATGA } \\
\text { GCCCGCGTCCGATTAGCTAGTTGGTGAGGTA } \\
\text { AAGGCTCACCAAGGCGACGATCGGTAGCCG } \\
\text { GCCTGAGAGGGTGTTCGGCCACAATGGAACT } \\
\text { GAGACACGGTCCATACTCCTACGGGAGGCA } \\
\text { GCAGTTAAGAATCTTGCTCAATGGGGGGAAC } \\
\text { CCTGAAGCAGCGACGCCGCGTGAACGATGA } \\
\text { AATTCCT }\end{array}$ & $\begin{array}{c}100 \%(364 / 364) \\
\text { AE010300.2 }\end{array}$ \\
\hline Kidney & $\begin{array}{c}\text { Bothrops } \\
\text { moojeni } \\
\text { G2 }\end{array}$ & $\begin{array}{l}\text { CTTCTTGGCGGCGCGTCTTAAACATGCAAGT } \\
\text { CAAGCGGAGTAGCAATACTCAGCGGCGAAC } \\
\text { GGGTGAGTAACACGTGGGTAATCTTCCTCTG } \\
\text { AGTCTGGGATAACTTTCCGAAAGGGAAGCTA } \\
\text { ATACTGGATGGTCCCGAGAGATCATAAGATT } \\
\text { TTTCGGGTAAAGATTTATTGCTCGGAGATGA } \\
\text { GCCCGCGTCCGATTAGCTAGTTGGTGAGGTA } \\
\text { AAGGCTCACCAAGGCGACGATCGGTAGCCG } \\
\text { GCCTGAGAGGGTGTTCGGCCACAATGGAACT } \\
\text { GAGACACGGTCCATACTCCTACGGGAGGCA } \\
\text { GCAGTTAAGAATCTTGCTCAATGGGGGGAAC } \\
\text { CCTGAAGCAGCGACGCCGCGTGAACGATGA } \\
\text { AATTCCT }\end{array}$ & $\begin{array}{c}100 \%(364 / 364) \\
\text { AE010300.2 }\end{array}$ \\
\hline
\end{tabular}

studied snakes came from farms and pastures, where they were probably infected by urine of affected cattle. According to Correa et al. (1965/1967) the predominant serovar in bovines is Hardjo prajtino. The seroprevalence of Hardjo serovar is observed in slaughterhouses and farm employees, suggesting that the exposure risk is related to direct and indirect contact with infected animals (Santa Rosa et al. 1980). Seroagglutination tests showed that bovines reacted positively (45.6\%) to serovar Hardjo according to Langoni et al. (2008).
Homem et al. (2001), researching humans and other animals in Amazonia, observed that serovar Hardjo was the most prevalent. Bovine leptospirosis is endemic in Brazil and may cause abortions, infertility, anorexia, jaundice, hemoglobinuria, mastitis and even death (Santa Rosa et al. 1972, Silva 1976, Simpson 2002, Langoni et al. 2004). Out of four pregnant jararacas (Bothrops) included in this study, three layed atresic eggs suggesting a possible influence of Leptospira on them. These findings indicate that egg atresia may be related to seropositivity to serovar Hardjo, however experimental studies 
and isolation of the agent are needed to corroborate this hypothesis.

Several studies have been carried out to determine the occurrence of Leptospira spp. and antibodies to Leptospira spp. in wild animals, but few include venomous or non venomous snakes. In Brazil this research was first performed by Hyakutake et al. (1976), in which agglutination tests detected Icterohaemorrhagiae, Ballum, Canicola, Guaicurus, Brasiliensis, Andamana and Javanica serovars. The predominant serovar founded by this authors was Andamana $(80.6 \%, N=25 / 31)$ and do not corroborate with our results that shown Hardjo prajtino as serovar predominant (88.5\%). This observation can be due the snakes came from different locations, and also the inclusion of new serovars, but few studies have been conducted until now.

Calle et al. (2001) found low-level Leptospira titers in freeranging Venezuelan anacondas (Eunectes murinus) and showed that this may represent previous infection, antibody responses to Leptospira antigens present in ingested prey, or antibodies to Leptospira serovars that were not included in the serologic panel.

Stanchi et al. (1986) analyzed 18 urutus-cruzeiro (Bothrops alternatus) for the presence of antileptospiral antibodies using a microscopic agglutination test, and observed $72.2 \%(\mathrm{~N}=13 / 18)$ of positive results to Patoc, Andamana, Wolffi, Tarassovi, Pomona, Pyrogenes and Shermani serovars.

The high prevalence of positive isolates in G2, when snakes were kept in individual boxes, may be explained by Abdulla \& Karstad (1962). These authors showed that snakes, both free-ranging and captive, may be infected by ingesting rodents and contaminated water. They also concluded that snakes might transmit leptospirosis by direct contact. The same authors, working with experimental serovar Pomona infection, found spirochetes in the kidneys of these animals six months after inoculation; interstitial nephritis was observed in one of them. Therefore, snakes in captivity may be infected by consuming infected mice or other food or water contaminated with their urine. This fact is demonstrated by the statistical difference between this group and the other G2, even in the collective captivity group, which has access to sunlight, water and more space per animal, as previously indicated by Ferreira Junior et al. (2010).

Ferris et al. (1961) isolated Leptospira interrogans serovar Ballum in an Eastern Hognose Snake (Heterodon platgrhinus). According to Hyakutake et al. (1976) the isolation of serovar Andamana in jararaca (Bothrops pradoi) may contribute to the transmission of leptospirosis to humans and other animals. Andrews et al. (1965) observed the presence of Leptospira ballum agglutinins in the serum of snakes of Southern Illinois, USA, as well as in other areas of the country. They concluded that these findings demonstrate the feeding habits of these animals.

According to Valentina \& Fratini (2005), there are no data of reptiles as source of infection of Leptospira to humans, though they may have direct contact with spirochetes in the environment. In the present study, there were animals with high titers such as 3200 , but without any clinical signs. Reptiles rarely show clinical disease when infected with Lep- tospira spirochetes, although seropositive snakes of various species have been reported with over 6400 titers (Santa Rosa et al. 1972, Cordeiro et al.1981).

MAT showed that snakes came into contact with the pathogen, with titers ranging from 100 to 3200 , PCR demonstrated that these animals harbored Leptospira interrogans. Several studies have been conducted employing the use of PCR for detection of Leptospira spp. in urine, serum and tissue of animals and humans (Gravekamp et al. 1993, Wagenaar et al. 2000, Bonfim et al. 2008). However, PCR had never been used to detect Leptospira spp. in snake tissues. Moreover, the present work showed that both wildlife and captivity snakes may maintain the pathogen without clinical signs.

Acknowledgements.- To Centro de Raízes Tropicais (Cerat)/ Unesp-Botucatu, SP, for facilities; to FAPESP for financial support (2008/51364-4); to Prof. Dr. Lidia Raquel de Carvalho for statistical analyses; and to Juliana S. Simionato for English support.

\section{REFERENCES}

Abdulla P.K. \& Karstad L. 1962. Experimental infections with Leptospira pomona in snakes and turtles. Zoonoses Res. 1:295-306.

Adler B. \& Moctezuma A.P. 2010. Leptospira and leptospirosis. Vet. Microbiol. 140:287-296.

Aguiar D.M., Gennari S.M., Cavalcante G.T., Labruna M.B., Vasconcellos S.A., Rodrigues A.A.R., Moraes Z.M. \& Camargo L.M.A. 2006. Seroprevalence of Leptospira spp. in cattle from Monte Negro municipality, western Amazon. Pesq. Vet. Bras. 26:102-104.

Andrews R.D., Reilly J.R., Ferris D.H. \& Hanson L.E. 1965. Leptospiral agglutinins in sera from southern Illinois herpetofauna. Bull. Wild. Dis. Assoc. 1:55-59.

Bonfim M.R.Q., Barbosa-Stancioli E.F. \& Koury M.C. 2008. Detection of pathogenic leptospires in urine from naturally infected cattle by nested PCR. Vet. J. 178:251-256.

Blancou J., Chomel B.B., Belotto A. \& Meslin F.X. 2005. Emerging or reemerging bacterial zoonoses: factors of emergence, surveillance and control. Vet. Res. 36:507-522

Calle P.P., Rivas J., Muñoz M., Thorbjarnarson J., Holmstrom W. \& Karesh W.B. 2001. Infectious disease serologic survey in free-ranging Venezuelan anacondas (Eunectes murinus). J. Zoo Wildl. Med. 32:320-323.

Cordeiro F., Sulzer C.R. \& Ramos A.A. 1981. Leptospira interrogans in several wildlife species in Southeast Brazil. Pesq. Agropec. Bras., Sér. Vet. 1:1929

Correa M.O.A., Hyakutake S., Natale V., Galvão P.A. \& Aguiar H.A. 1965/1967. Estudos sobre a Leptospira wolffi em São Paulo. Revta Inst. Adolfo Lutz, São Paulo, 25/27:11-25.

Faine S. 1982. Guideline for the Control of Leptospirosis. $2^{\text {nd }}$ ed. WHO, Geneva, Offset Publication 67:171.

Ferreira Junior R.S., Biscola N.P., Campagner M.V. \& Barraviera B. 2010. How to raise snakes in captivity? Vet. Microbiol. 141:189.

Ferris D.H., Rhoades H.E., Hanson L.E., Galton M. \& Mansfield M.E. 1961. Research into the nidality of Leptospira ballum in campestral hosts including the hog-nosed snake (Heterodon platgrhinus). Cornell Vet. 51:405419.

Ghneim G.S., Viers J.H., Chomel B.B., Kass P.H., Descollonges D.A. \& Johnson M.L. 2007. Use of a case-control study and geographic information systems to determine environmental and demographic risk factors for canine leptospirosis. Vet. Res. 38:37-50

Gravekamp C., Van de Kemp H., Franzen D., Carrington D., Schoone G.J., Van Eys G.J.J.M., Everard C.O.R., Hartskeerl R.A. \& Terpstra W.J. 1993. Detection of seven species of pathogenic leptospires by PCR using two sets of primers. J. Gen. Microbiol. 139:1691-1700.

Hashimoto V.Y., Gonçalves D.D., Silva F.G., Oliveira R.C., Alves L.A., Reichmann P., Muller E.E. \& Freitas J.C. 2007. Occurrence of antibodies against Lep- 
tospira spp. in horses of the urban area of Londrina, Paraná, Brazil. Revta. Inst. Med. Trop. 49:327-330.

Homem V.S.F., Heinemann M.B., Moraes Z.M., Vasconcellos S.A., Ferreira F. \& Ferreira Neto J.S. 2001. Estudo epidemiológico da leptospirose bovina e humana na Amazônia oriental brasileira. Revta. Inst. Med. Trop. 34:173180.

Hyakutake S., Biasi P.D., Santa Rosa C.A. \& Belluomini H.E. 1976. Contribuição ao estudo epidemiológico das leptospiroses em serpentes do Brasil. Rev. Inst. Med. Trop. 18:10-16.

Hyakutake S., Biasi P.D., Belluomini H.E. \& Santa Rosa C.A. 1980. Leptospiroses in Brazilian snakes. Int. J. Zoonoses 7:73-77.

Langoni H., Da Silva A.V., Pezerico S.B. \& De Lima V.Y. 2004. Anti-leptospire agglutinins in equine sera, from São Paulo, Goias, and Mato Grosso do Sul, Brazil. 1996-2001. J. Venom. Anim. Toxins incl. Trop. Dis. 10:207218.

Langoni H., Souza L.C., Da Silva A.V., Cunha E.L.P. \& Silva R.C. 2008. Epidemiological aspects in leptospirosis: Research of anti-Leptospira spp. antibodies, isolation and biomolecular research in bovines, rodents and workers in rural properties from Botucatu, SP, Brazil. Braz. J. Vet. Res. Anim. Sci. 45:190-199.

Mérien F., Amouriaux P., Perolat P., Baranton G. \& Saint Girons I. 1992. Polymerase chain reaction for detection of Leptospira spp. in clinical samples. J. Clin. Microbiol. 30:2219-2224.

Romero E.C., Yasuda P.H. 2006. Molecular characterization of Leptospira sp. strains isolated from human subjects in São Paulo, Brazil using a polymerase chain reaction-based assay: A public health tool. Mem. Inst. Oswaldo Cruz 101:373-378.
Santa Rosa C.A., Sulzer C.R. \& Castro A.F.P. 1972. A new leptospiral serotype in the Bataviae group, isolated in São Paulo, Brazil. Am. J. Vet. Res. 33:1719-1721.

Santa Rosa C.A., Sulzer C.R., Castro A.F.P., Yanaguita R.M. \& Giorgi W. 1980. Two new serovars in the hebdomadis group isolated from cattle in Brazil. Int. J. Zoonoses 7:158-163.

Silva I. 1976. A new leptospiral serotype isolated in Salvador, Bahia State. Revta Microbiol, São Paulo, 73:5-37.

Simpson V.R. 2002. Wild animals as reservoirs of infectious diseases in the UK. Vet. J. 163:128-146.

Stanchi N.O., Grisolía C.S., Martino P.E. \& Peluso F.O. 1986. Presence of antileptospira antibodies in ophidia in Argentina. Revta Argent. Microbiol. 18:127-130.

Valentina V.E. \& Fratini F. 2005. Bacterial zoonoses among domestic reptiles. Zoonosi batteriche trasmesse da rettili domestici. Ann. Fac. Med. Vet. 58:85-91.

Wagenaar J.A., Zuerner R.L., Alt D. \& Bolin C.A. 2000. Comparison of polymerase chain reaction assays with bacteriologic culture, immunofluorescence, and nucleic acid hybridization for detection of Leptospira borgpetersenii serovar hardjo in urine of cattle. Am. J. Vet. Res. 61:316320.

Weekes C.C., Everard C.O.R. \& Levett P.N. 1997. Seroepidemiology of canine of leptospirosis on the island of Barbados. Vet. Microbiol. 51:215-222.

World Organization for Animal Health Animal, OIE. Downloaded in April 2010 from http://www.oie.int/.

Zar J.H. 1999. Bioestatistical Analysis. $4^{\text {th }}$ ed. Prentice Hall, New Jersey. 663p. 